\title{
Review Studies of GJB2 Gene in Patients with Hearing Impairment in Pakistan
}

\author{
Farooqi $\mathbf{N}^{*}$, Khan O, Ellaham $\mathbf{S}$ and Jalil SF \\ Faculty of Chemical and Life Sciences, Department of Biotechnology, Abdul Wali Khan University Mardan, Pakistan
}

\begin{abstract}
Deafness is inherited as one of the most frequent type of neurosensory disorder. The specific physiologic mechanisms of the different types of hearing loss are still unknown. Recent studies have listed numerous causative agents for hearing loss. Genetic factors contribute to a greater extent in hearing disability. GJB2 gene is one of the most promising candidates. 35delG is the most common mutation which accounts for about $50 \%$ of all GJB2 gene mutation. After collection of data and isolation of blood, extraction of DNA was performed for each sample. Direct sequencing of GJB2 gene was performed. Primary sequencing data of the representative sample concluded that GJB2 gene is not mutated in the studied family. There are other candidates for hearing disability; further investigations are needed for assessment of other members of the selected family or other genes that are responsible for hearing loss. Human GJB2 protein was compared with that of mouse and rabbit. The data from multiple alignment shows that there is only alteration at nine different points of rabbit compared to human $G J B 2$ protein while this variation is sixteen times when we compared human GJB2 protein sequence with that of mouse.
\end{abstract}

Keywords: Deafness; GJB2 gene; Hereditary deafness; X-linked recessive

\section{Introduction}

Hearing loss (HL) or hearing impairment (HI) is the most common and frequent neurosensory disorder in human populations [1]. It is defined as partial or complete loss of hearing due to which the individuals are unable to develop normal speech, language and communication skills [2].

\section{Prevalence of deafness}

Hearing loss occurs at the frequency of 1 in 2000 to 1 in 650 births [1]. Nearly $10 \%$ of worldwide genetic deafness is estimated to be caused by consanguineous marriages [3].

Usher syndrome (USH), is a type of hearing loss. It is highly heterogeneous in nature that is associated with bilateral nonsyndromic autosomal recessive sensorineural deafness and retinitis pigmentosa (RP) or rod-cone dystrophy [4-6]. The worldwide prevalence of Usher syndrome (USH), causing HL and blindness is up to 1 in $23,000[7,8]$. It affects 1.86 in 1000 newborn babies in which half of it is due to genetic causes [1]. It is responsible for autosomal recessive $\mathrm{HL}$ at the frequency of $1-10 \%$ in children and about 3-5 in 10,000 of general population [7]. In European populations, Usher syndrome accounts for 3-4 in 100,000 $[7,9]$. There are different types of USH i.e., USH1, USH2, USH3. USH1 affected people (25-44\%), USH2 cases (56-75\%) and USH3 (2\%) were found in Europe [10-13]. The prevalence of Usher syndrome in the United States is predicted to be 4.4 per 100,000 individuals [7] and in Scandinavia, it is 3.5 in 100,000 people $[12,14,15]$. Epidemiological study has shown that about $25 \%$ people are diagnosed with presbycusis (age related hearing impairment ARHL) at the age of 60 years, while this ratio has increased twice (50\%) with increase in the age (80 years) $[16,17]$. It was estimated that out of 600 million worldwide deaf people about 400 million stay in the developing countries [18]. The prevalence frequency of noise induced HL (NIHL) was reported to be $7 \%$ and $21 \%$ in the Western population and developing countries, respectively [19]. The estimated prevalence of deafness in the UK is 14\% [20] (Davis, 1987). It is thought that there are approximately 35,000 young people and deaf children in the UK. Nearly 850 affected children are born annually and 1-2 in 1000 neonates will be suffering from HL (www. earlysupport.org.uk). 20\% (nearly 52 million) of affected adults and 36\% of 55 years old deaf individuals was estimated in Europe [21]. According to estimation, deaf patients were found to occur in a prevalence ratio of $14.3 \%$ and $16.9 \%$ in Denmark and Sweden, respectively [22,23]. From a multicenter survey conducted in the North America, the number of deaf individuals was estimated to be about 25 million in 300 million people [24]. The prevalence of prelingual HL in the USA is reported to be $4-11$ in 10,000 children [25].

The inheritance pattern of deafness is autosomal recessive in Pakistani population [25]. According to estimation, bilateral profound HL is up to 1.6 in 1000 and $70 \%$ of deafness is seen in consanguineous Pakistani families [26]. Nearly $30 \%$ of genetic deafness is predicted to be caused by consanguineous marriages in Pakistan and in the Middle East [3]. It is also found that nearly $60 \%$ of Pakistani marriages are consanguineous as a result of cultural conditions and about $80 \%$ of them are between the first cousins [27]. 5\% cases of severe to profound HL are caused by mutation of MYO15A gene in Pakistan [2]. Prevalence of X-linked heterogeneous nonsyndromic deafness is up to $1-5 \%[28,29]$. DFNB locus genes were thought to be involved in recessive, prelingual HL. The prevalence of DFNB4 locus is up to $7.2 \%$ in this population [30]. A recessive deafness locus DFNB49 was first identified at $5 \mathrm{q} 13$ chromosome in two Pakistani populations [31]. The estimated prevalence frequency of autosomal recessive nonsyndromic deafness loci DFNB23, DFNB39, DFNB7/11, DFNB8/10, DFNB9/48, DFNB3/12, DFNB2, DFNB1 and DFNB4 was found to be $1.83 \%, 2.19 \%$, $2.65 \%, 3.01 \%, 3.01 \%, 3.93 \%, 5.66 \%, 5.94 \%$ and $7.58 \%$ respectively [32].

*Corresponding author: Dr. Nadia Farooqi, Faculty of Chemical and Life Sciences Department of Biotechnology, Abdul Wali Khan University Mardan, Pakistan, Tel: +929379230640; E-mail: farooqinadia2@gmail.com

Received December 20, 2017; Accepted December 28, 2017; Published December 29, 2017

Citation: Farooqi N, Khan O, Ellaham S, Jalil SF (2017) Review Studies of GJB2 Gene in Patients with Hearing Impairment in Pakistan. J Mol Genet Med 11: 316 doi:10.4172/1747-0862.1000316

Copyright: ( 2017 Farooqi N, et al. This is an open-access article distributed under the terms of the Creative Commons Attribution License, which permits unrestricted use, distribution, and reproduction in any medium, provided the original author and source are credited 


\section{Structure and Function of Auditory System}

The anatomy of the human ear, the organ of auditory system and balance, consists of the outer, middle and inner ear also called the labyrinth [33]. The external ear is composed of auricle or pinna, ear canal, and tympanic membrane or eardrum membrane [34]. Diagram of human ear illustrating the outer, middle and inner ear (modified from www.webmd.com).

The external ear serves to protect the inner delicate parts of the auditory system. It prevents the auditory system from harmful infections and from clogging by the entrance of foreign antigen or bacteria. It consists of squamous keratinized epithelial cells and protects the inner and middle ear [32]. After receiving the sound waves, external ear transfers them to the eardrum in the middle ear through the ear canal [34]. Three smallest and tiny bones of the middle ear (called the ossicles: malleus, anvil and stapes or hammer, anvil and stirrup, respectively) carry the sound waves through the oval window into a snail shaped spiral bony organ, $35 \mathrm{~mm}$ in length, the cochlea in the inner ear [34]. Cochlea detects the sound stimulus through auditory receptors called organ of Corti [34].

The pressure of the sound waves vibrates the tectorial membrane on the top of the hair cells [35]. These vibrations in the organ of Corti produce sound transduction which is detected by receptor cells called the hair cells [36]. The hair cells and the fluid move as a result of these vibrations (www.earlysupport.org.uk). These cells produce electrical impulses or signals that are conveyed by nerves to the brain where they are interpreted in the left side of the brain (inferior colliculus or IC) [36]. The IC (a hemispherical mass of nerves) forms the greatest part of the midbrain. It serves as a principal auditory center and helps in the integration of hearing reflexes (inner.com/nerve 88-new.ht $\mathrm{ml}$ ) or it is a part of the midbrain that functions as an important auditory center in the body. It exists as a pair of lower lobes which helps in processing the auditory signals from both the ears. Its three subdivisions are called the external, lateral and central cortex. Its metabolic activity is higher as compared to other parts of the brain. It also contributes in processes like signal integration, pitch detection, frequency recognition and processing sensory signals from the superior colliculi (health.yahoo. net/human-body-maps/). The normal hearing threshold is 15 decibel (dB) [36]. The frequency range of 20-20,000 pulses per second is audible by a normal human ear [32].

\section{Genetic based hearing disabilities}

Genetic hearing loss is a diverse and heterogeneous trait. There are numerous biotic as well as abiotic factors contributing in HL. Some of abiotic factors include viral and bacterial infections in infants, teratogens, high bilirubin content in blood, autotoxic drugs, head injury, loud noise and using antibiotic medications $[37,38]$.

There are about 100 different candidate genes of HL [39]. Genetic or hereditary deafness is up to $50 \%$ that can be either syndromic (30\%) or non-syndromic (70\%) [40,41]. In syndromic hearing loss (SHL), the individuals are affected with other clinical features beside deafness, while in NSHL, no additional signs can be seen in individuals [36]. Syndromic deafness can be dominant, recessive and X-linked [42]. Based on the position of damage and type of ear defect, syndromic HL can be conductive, sensorineural or mixed HL [36]. Conductive HL occurs when sound waves are unable to pass properly from the outer and middle ear to the cochlea. It is caused by congenital abnormalities like atropy, dysplasia, malformation and clogging of the middle and outer ear, otitis media or glue ear, the three small bones of the middle ear are unable to move as a result of the middle ear fluid or glue ear. Sensorineural HL occurs in the cochlea or the auditory nerve [43]. Nonsyndromic HL is sensorineural impairment [42]. Unlike conductive HI, sensorineural HL is permanent and cannot be treated (www.earlysupport.org.uk). Moreover, NSHL shows autosomal recessive $(\mathrm{AR})$, autosomal dominant $(\mathrm{AD})$, $\mathrm{X}$-linked $(\mathrm{XL})$, Y-linked (YL) and mitochondrial mode of inheritance, the most severe and important form being the autosomal recessive i.e., 75\% of NSHL is shown as AR pattern in affected families [37,41]. While AD cases are of $10-20 \%, 1-5 \%$ cases are inherited as X-linked recessive and genetic deafness is inherited by $1 \%$ human genome [44]. All these forms show monogenic traits while digenic inheritance has also been reported [43]. Gap junction $\beta 2$ (GJB2) or Connexin 26 (Cx26) is one of the prominent candidate of hearing loss. Therefore, it was screened for mutations with direct sequencing method.

\section{Structure and function of GJB2 gene}

GJB2 (Gap junction $\beta 2$ ) or Connexin 26 (Cx26), is a small gene of molecular weight $26 \mathrm{kDa}$, comprising $5.5 \mathrm{~Kb}$ or $5500 \mathrm{bp}$. It consists of two exons (about $2311 \mathrm{bp}$ ) separated by an intron. Exon 2 is protein encoding. The size of encoded mRNA is $4.2 \mathrm{~Kb}$ while the protein has 226 amino acid residues [45].

GJB2 is expressed in various body organs including the limbus, basement membrane and spiral prominence of the mammalian cochlea and hepatocytes [46,47]. It encodes certain transmembrane gap junction proteins known as Connexins (having similar topology) [48]. The passage of small metabolites $(<1000$ Dalton $)$ and inorganic ions between the adjacent cells is regulated by these proteins $[49,50]$. They are also important for the growth and differentiation of keratinocytes in the epidermis [51]. These proteins are present in the fibrocytes of the cochlear duct and the epithelial supporting cells, lining the sensory ear cells of the cochlea [52]. Six molecules of connexin oligomerise to form a hemi-channel connexon. Two connexons of the adjacent plasma membranes form a channel which makes the gap junctions through disulphide linkages.

To briefly explain, gap junction channels allow the transfer of different solute molecules across the plasma membrane of adjacent cells. These include ions, metabolites, peptides, nucleotides and secondary messengers. These channels play vital role in many biologically important processes like auditory transduction by recycling $\mathrm{K}^{+}$ions in the cochlea, electrical signaling in the nervous system, growth of epidermal keratinocytes, cardiac development, the immune system, fertility, homeostasis and maintanence [53]. There is a high concentration of $\mathrm{K}^{+}$ ions, low $\mathrm{Na}^{+}$ions and $\mathrm{Ca}^{+2}$ ions concentration outside in endolymph. The gap junctions help in the potassium recycling from the hair cells into the endolymph at the upper surface of the sensory ear cells during the sound transduction. Influx of $\mathrm{K}^{+}$and $\mathrm{Ca}^{+2}$ ions causes the hair cells to depolarize and releases the neurotransmitter. This recycling helps in the normal function of cochlea and sensorineural hearing $[42,45]$. In case of genetic alteration in GJB2, abnormal synthesis of connexin, impaired potassium cycle, cell death and finally bilateral non-syndromic HL occurs $[54,55]$. The second connexin gene (GJB6, 35-kb downstream of the GJB2 gene on 13q12 chromosome) is expressed in the same innerear structures and both the gap junction proteins are functionally related [56]. The cell-to-cell interactions are mediated by different connexins that organize themselves in a complex way within connexons. This complex arrangement is referred to as "connexin code" [57].

\section{Contribution of GJB2 gene mutation in deafness}

GJB2 gene is located on DFNB1 locus, initially identified by linkage analysis using the markers D13S143, D13S175, D13S292 in a large 
Tunisian family. It was mapped to chromosome $13 \mathrm{q} 12-\mathrm{q} 13$ in two consanguineous families [58]. After three years, it was shown that $C \times 26$ gene mutations are responsible for HL [59]. Approximately, 90 different GJB2 variants have been identified (The Connexin-Deafness Homepage: http;//davinci.crg.es/deafness/). It has been reported that autosomal recessive nonsyndromic hearing loss (ARNSHL) results from GJB2 gene mutations in many cases [60,61]. It causes $50 \%$ HL in children in some populations [62]. GJB2 gene mutation is responsible for $50 \%$ of profound HL cases, severe HL cases: $30 \%$, moderate: $20 \%$ and $1-2 \%$ of mild HL [63]. In addition, a high frequency of this gene mutation has been observed in some of the ethnic groups [64]. Similarly, $50 \%$ of autosomal recessive non-syndromic deafness in the Caucasians is due to GJB2 mutations [65]. At position 30-35 of coding region of GJB2 gene, there is a small repeated sequence of six $G$ residues. If there is deletion of one $G$ residue in codon 10 , then the mutation is referred to as $30 \mathrm{delG}$ or $35 \mathrm{delG}$ [46]. It was identified by the method proposed by Storm et al. [66]. 35delG, the most frequent mutation in the Caucasians, is responsible for $70 \%$ of GJB2 mutations. The most prevalent nonsense mutation W24X truncating Cx26 protein (24 amino acids), was first reported in a Pakistani family [65]. The GJB2 mutations which cause syndromic HL include: delE42, [67], G12R, D50N and S17F [68], G59A [69], N54K [70], R75Q [71], R75W [72], D66H [73], G130V [74]. While autosomal dominant non-syndromic HL is caused by $\mathrm{C} 202 \mathrm{~F}$ [75], R143Q [76], W44C [77], R184Q [78], D179N [79] and G21R gene mutation. It lies in the first intracellular domain [80]. C202F mutation is located in the M4 transmembrane domain of the GJB2 protein. This domain functions in the oligomerisation of connexins. Heterozygous W44C mutation is present in the extracellular loop E1 (allows the interactions between adjacent cells connexons) of the protein. Other known GJB2 mutations are E47X, I20T, R184P, L90P, delE120 and V95M [81].

\section{Clinical features of deafness}

Diagnosis of deaf individuals is related to the characteristic signs and symptoms of deafness. Up to 151 different forms of inherited deafness have been discovered [82]. Hereditary deafness is associated with more than 500 syndromes [83]. On the basis of clinical symptoms like onset of retinitis pigmentosa, severity of deafness and vestibular response, the autosomal recessive Usher syndrome has been classified into type 1 , type 2 and type 3 , the most severe being the type 1 [84]. Narrow blood vessels, pale optic disc and balance problems are also observed in individuals affected with USH [85]. Beside these, symptoms like structural anomalies of nasal cilia $[86,87]$, olfactory loss is also found in the USH patients [88]. The characteristic features of X-linked Alport syndrome are ocular problems, hematuria, glomerulonephritis, renal failure and sensorineural deafness. These symptoms are more common in men than women. Uremia can also lead to death in men [89]. Based on the clinical symptoms like cleft palate, osteoarthritis, sensorineural HL, vertebral abnormalities, unusual facial features and eye problems, autosomal dominant Stickler syndrome (STL) is divided into four types (type 1, 2, 3 and 4) [90]. The AD Neurofibromatosis type 2 (NF 2) is characterized by gliomas, meningiomas, unilateral sensorineural deafness, headache, imbalance, skin tumor, tumors of the hearing and balance nerve and tinnitus. Autosomal recessive Pendred disease is characterized by goiter (abnormal metabolism of iodine) [91]. The characteristic signs of autosomal dominant Branchio-oto-renal (BOR) syndrome include kidney problems, neck cysts, branchial and otologic anomalies (Mondihni's dysplasia, stapes fixation), long narrow face and cup shaped pinnae [92]. Similarly, hereditary and acquired mitochondrial mutations are related to many signs and symptoms such as diabetes mellitus, myopathy, neuropathy, sensorineural HL, presbycusis or ARHL and aging [93,94]. A few symptoms like night blindness, hair depigmentation, skin pigment changes, nausea, vomiting, severe dizziness, headache, pain, thyroid dysfunction, tinnitus, ear and respiratory tract infections are also seen in deafness [95]. The anomalies caused by Norrie disease (a syndrome associated with X-linked HL) include bilateral blindness, bilateral sensorineural HL, mental retardation and microphthalmia [96,97]. Poor growth, microcephaly, seizures, delay in sexual maturity, cardiovascular problems, pulmonary arterial hypertension and psychomotor retardation like complex symptoms are also seen in some patients [98-105]. Patients affected by AR Biotinidase deficiency syndrome shows the signs like deafness, hair loss, seizures, emesis, skin rashes and acidosis.

\section{Audiological and vestibular function assessments}

Before hearing tests, blood samples are subjected to DNA testing for diagnosis of GJB2 alterations. With the advancement in technology, there are various approaches that can be used for testing of hearing threshold level of patients. These techniques are electrophysiological tests (Auditory brain-stem responses (ABR), searching for mutations in connexin 26 gene, behavioral audiometry, evoked response audiometry, electrococleography (EcochG), otoacoustic emission testing, tympanometry, pure-tone and speech audiometry, Pure tone air conduction audiometry, Early Speech Perception (ESP) test, Speech discrimination test, Visual Reinforcement Audiometry (VRA), Play audiometry, bone conduction audiometry.

\section{Conclusion}

As per the above studies, it can be concluded that while Romberg and Tandem Gait test, Electronystagmography (ENG) test are used for clinical assessment of vestibular function. ENG test graphically records eye movements to analyze the sources of dizziness, balance dysfunction and has further three parts; occulomotor evaluation, positional testing and caloric measurement.

\section{References}

1. Morton CC, Nance WE (2006) New born hearing screening- A silent revolution New Engl J Med 354: 2151-2164

2. Friedman TB, Griffith AJ (2003) Human non-syndromic sensorineural deafness Hum Mol Genet 14: 342-431.

3. Alwan A, Modell B (1997) Community control of genetic and congenita disorders. EMRO technical publication series 24. WHO Regional Office for the Eastern Mediterranean, Alexandria, Egypt.

4. Keats BJ, Savas S (2004) Genetic heterogeneity in Usher syndrome. Am J Mol Genet 130: 13-16.

5. Reiners J, Nagel-Wolfrum K, Jurgens K, Marker T, Wolfrum U (2006) Molecular basis of human Usher syndrome: deciphering the meshes of the Usher protein network provides insights into the pathomechanisms of the Usher disease. Exp Eye Res 83: 97-119.

6. Hartong DT, Berson EL, Dryja TP (2006) Retinitis pigmentosa. Lancet 368 1795-1809.

7. Boughman JA, Vernon M, Shaver KA (1983) Usher syndrome: definition and estimate of prevalence from two high-risk populations. J Chronic Dis 36: 595603.

8. Keats BJ, Corey DP (1999) The usher syndromes. Am J Med Genet 89: 158166.

9. Forsius H, Eriksson A, Nuutila A, Vainio-Mattila B, Krause U (1971) A genetic study of three rare retinal disorders: dystrophia retinae dysacusis syndrome $\mathrm{x}$-chromosomal retinoschisis and grouped pigments of the retina. Birth Def Orig Article Series 7: 83-98

10. Hope Cl, Bundey S, Proops D, Fielder AR (1997) Usher syndrome in the city of Birmingham--prevalence and clinical classification. Brit J Ophthal 81: 46-53. 
Citation: Farooqi N, Khan O, Ellaham S, Jalil SF (2017) Review Studies of GJB2 Gene in Patients with Hearing Impairment in Pakistan. J Mol Genet Med 11: 316 doi:10.4172/1747-0862.1000316

Page 4 of 5

11. Rosenberg T, Haim M, Hauch AM, Parving A (1997) The prevalence of Usher syndrome and other retinal dystrophy-hearing impairment associations. Clin Genet 51: 314-321.

12. Grondahl, J (1987) Estimation of prognosis and prevalence of retinitis pigmentosa and Usher syndrome in Norway. Clin Genet 31: 255-264.

13. Spandau UH, Rohrschneider K (2002) Prevalence and geographical distribution of Usher syndrome in Germany. Graefes Arch Clin Exp Ophthal 240: 495-498.

14. Hallgren B (1959) Retinitis pigmentosa combined with congenital deafness, with vestibulo-cerebellar ataxia and neural abnormality in a proportion of cases. Acta Psychiatr Scand Suppl 138: 1-101

15. Nuutila A (1970) Dystrophia retinae pigmentosa-Dysacusis syndrome (DRD): A study of the Usher, or Hallgren, syndrome. J Hum Genet 18: 57-88.

16. Dror AA, Avraham KB (2009) Hearing loss: Mechanisms revealed by genetics and cell biology. Ann Rev Genet 43: 411-437.

17. Huang Q, Tang J (2010) Age-related hearing loss or presbycusis. Europ Arch Otorhinolary 267: 1179-1191.

18. CBM (2011) Hearing loss in the developing world.

19. Nelson DI, Nelson RY, Cocha-Barrientos M (2005) The global burden of occupational noise induced hearing loss. Am J Med Genet 48: 446-458.

20. Davis AC (1987) Epidemiology of hearing disorders. In: Scott-Brown's Otolaryngology, AG Kerr, (ed). Butterworths, London.

21. Anteunis $L$ (1999) hearing aids bring enormous benefits for society - concludes pilot study. European Hearing Instrument Manufacturers Association, Lautrupbjerg.

22. Karlsmose B, Lauritzen T, Engberg M, Parving A (2000) A five-year longitudinal study of hearing in a Danish rural population aged 31 to 50 years. Brit J Audio 34: $47-55$

23. Johansson MSK and Arlinger SD (2003) Prevalence of hearing impairment in a population in Sweden. Int JAudiol 42: 18-28.

24. Kochkin S (2011) Prevelance of hearing loss, Better Hearing Institute Washington, D.C., USA.

25. Marazita ML, Ploughman LM, Rawlings B, Remington E, Arons KS, et al. (1993) Genetic epidemiological studies of early onset deafness in U.S. schoolage population. Am J Med Genet 46: 486-491.

26. Elahi M, Elahi F, Elahi SB (1998) Paediatric hearing loss in rural Pakistan. J Otolaryngol 27: 348-353.

27. Hussain R, Bittles AH (1998) The prevalence and demographic characteristics of consanguineous marriages in Pakistan. J Biosoc Sci 30: 261-275.

28. Cohen MM, Gorlin RJ (1995) Epidemiology, Etiology and Genetic Patterns. In Hereditary Hearing Loss and its Syndromes. Oxford University Press, USA.

29. Petersen MB, Wang Q, Willems PJ (2008) Sex-linked deafness. Clin Genet 73: $14-23$.

30. Anwar S, Riazuddin S, Ahmed ZM, Tasneem S, Ateeq-Ul-Jaleel, et al. (2009) SLC26A4 mutation spectrum associated with DFNB4 deafness and Pendred's syndrome in Pakistanis. J Hum Genet 54: 266-270.

31. Ramzan K, Shaikh RS, Ahmad J, Khan SN, Riazuddin S, et al. (2005) A new locus for nonsyndromic deafness DFNB49 maps to chromosome 5q12.3-q14.1. Hum Genet 116: 17-22

32. Shabbir MI (2008) Prevalence of different deafness loci in Pakistani inbred families. National Center of Excellence in Molecular Biology, University of the Pubjab, Lahore, Pakistan.

33. Hudspeth AJ (1989) How the ear's works work. Nature 341: 397-404.

34. Raphael Y, Altschuler RA (2003) Structure and innervation of the cochlea Brain Res Bullet 60: 397-422.

35. Richardson GP, Lukashkin AN, Russell IJ (2008) The tectorial membrane: One slice of a complex cochlear sandwich. Curr Opin Otolaryngol Head Neck Surg 16: $458-464$

36. Mahdieh N, Rabbani B (2009) Statistical study of 35delG mutation of GJB2 gene: A meta-analysis of carrier frequency. Int J Audiol 48: 363-370.

37. Willems PJ (2004) Gene localization and isolation in nonsyndromic hearing loss. In: Genetic Hearing Loss. Marcel Dekker Inc, New York, USA.
38. Shin JJ, Keamy DG, Steinberg EA (2011) Medical and surgical interventions for hearing loss associated with congenital cytomegalovirus: A systematic review. Otolaryngol Head Neck Surg 144: 662-675.

39. Bitner J, Glindzicz M (2002) Hereditary deafness and phenotyping in humans. Brit Med Bullet 6: 73-94.

40. Gorlin RJ, Toriello HV, Cohen MM (1995) Hereditary hearing loss and its syndromes. Oxford University Press, New York, USA.

41. Tekin M, Arnos KS, Pandya A (2001) Advances in hereditary deafness. Lancet 358: $1082-1090$.

42. Petit C, Levilliers J, Hardelin JP (2001) Molecular genetics of hearing loss. Ann Rev Genet 35: 589-646.

43. Friedman TB, Griffith AJ (2003) Human nonsyndromic sensorineural deafness. Ann Rev Genom Hum Genet 4: 41-402.

44. Finsterer J, Fellinger $\mathrm{J}(2000)$ Nuclear and mitochondrial genes mutated in nonsyndromic impaired hearing. Int J Pedia Otorhinolaryng 69: 621-647.

45. Kelley PM, Harris DJ, Comer BC, Askew JW, Fowler T, et al. (1998) Nove mutations in the connexin 26 gene (GJB2) that cause autosomal recessive (DFNB1) hearing loss. Am J Hum Genet 62: 792-799.

46. Grifa A, Wagner CA, D'Ambrosio L, Melchionda S, Bernardi F, et al. (1999) Mutations in GJB6 cause nonsyndromic autosomal dominant deafness at DFNA3 locus. Nature Genet 23: 16-18.

47. Lautermann J, Frank HG, Jahnke K, Traub O, Winterhager E (1999) Developmental expression patterns of connexin 26 and -30 in the rat cochlea. Develop Genet 25: 306-311.

48. Holms RH, Steel KP (1999) Genes involved in deafness. Curr Opin Genet Develop 9: 309-314.

49. Bruzzone R (2001) Learning the language of cell-cell communication through connexin channels. Genome Biol 2: 1-5.

50. Bruzzone R, Veronesi V, Gomes D, Bicego M, Duval N, et al. (2003) Loss offunction and residual channel activity of connexin 26 mutations associated with non-syndromic deafness. FEBS Letters 533: 79-88.

51. Choudhry R, Pitts JD, Hodgins MB (1997) Changing patterns of gap junctional intercellular communication and connexin distribution in mouse epidermis and hair follicles during embryonic development. Develop Dynam 210: 417-430.

52. Kikuchi T, Kimura RS, Paul DL, Adams JC (1995) Gap junctions in the rat cochlea: immunohistochemical and ultrastructural analysis. Anat Embry 19: 101-118.

53. Harris A L (2001) Quaterly Reviews of Biophysics 34: 325-472.

54. Morell RJ, Kim HJ, Hood LJ, Goforth L, Friderici K, et al. (1998) Mutations in the connexin 26 gene (GJB2) among Ashkenazi Jews with non-syndromic recessive deafness. New Eng J Med 339: 1500-1505.

55. Abe S, Usami S, Shinkawa H, Kelley PM, Kimberling WJ (2000) Nonlinear effect on noise power spectrum for quantum mottle in radiographs. J Med Genet 37: 41-48.

56. Lautermann J, Frank HG, Jahnke K, Traub O, Winterhager $\mathrm{E}$ (1999) Developmental expression patterns of connexin 26 and -30 in the rat cochlea. Devel Genet 25: 306-311.

57. Kelsell DP, Dunlop J, Hodgins B (2001) Human diseases: Clues to cracking the connexin code? Trends Cell Biol 11: 2-6.

58. Guilford P, Ben Arab S, Blanchard S, Levilliers J, Weissenbach J, et al (1994) non-syndrome form of neurosensory, recessive deafness maps to the pericentromeric region of chromosome 13q. Nature Genet 6: 24-28.

59. Schrijver I (2004) Hereditary non-syndromic sensorineural hearing loss: Transforming silence to sound. J Mol Diag 6: 275-284.

60. Bayazit YA, Cable BB, Cataloluk O, Kara C, Chamberlin P, et al. (2003) GJB2 gene mutations causing familial hereditary deafness in Turkey. Int $\mathrm{J}$ Ped Otorhinolaryngol 67: 1331-1335.

61. Mustafa MW (2004) Prevalence of the connexin-26 mutation 35delG in nonsyndromic hearing loss in Egypt. Int J Otorhinolaryng 3: 1.

62. Estivill X, Govea N, Barcelo E (1998) Familial progressive sensorineural deafness is mainly due to the mtDNA A1555G mutation and is enhanced by treatment of aminoglycosides. Am J Hum Genet 62: 27-35. 
Citation: Farooqi N, Khan O, Ellaham S, Jalil SF (2017) Review Studies of GJB2 Gene in Patients with Hearing Impairment in Pakistan. J Mol Genet Med 11: 316 doi:10.4172/1747-0862.1000316

Page 5 of 5

63. Smith RJ, Hone S (2003) Genetic screening for deafness. Pediatric Clinics North Am 50: 315-329.

64. Morell RJ, Kim HJ, Hood LJ, Goforth L, Friderici K, et al. (1998) Mutations in the connexin 26 gene (GJB2) among Ashkenazi Jews with nonsyndromic recessive deafness. New Eng J Med 339: 1500-1505.

65. Kelsell DP, Dunlop J, Stevens HP, Lench NJ, Liang JN, et al. (1997) Connexin 26 mutations in hereditary non-syndromic sensorineural deafness. Nature 387 : 80-83.

66. Storm K, Willocx S, Flothmann K, Camp G (1999) Determination of the carrie frequency of the common GJB2 (connexin-26) 35delG mutation in the Belgian population using an easy and reliable screening method. Hum Mut 14: 263-266.

67. Rouan F, White TW, Brown N, Taylor AM, Lucke TW, et al. (2001) transdominant inhibition of connexin-43 by mutant connexin- 26: Implications for dominant connexin disorders affecting epidermal differentiation. J Cell Sci 114: 2105-2113.

68. Richard G, Rouan F, Willoughby CE, Brown N, Chung P, et al. (2002) Missense mutations in GJB2 encoding connexin-26 cause the ectodermal dysplasia keratitisichthyosis- deafness syndrome. Am J Hum Genet 70: 1341-1348.

69. Heathcote K, Syrris P, Carter ND and Patton MA (2000) A connexin 26 mutation causes a syndrome of sensorineural hearing loss and palmoplantar hyperkeratosis (MIM 148350). J Med Genet 37: 50-51.

70. Richard G, Brown N, Ishida-Yamamoto A, Krol A (2004) Expanding the phenotypic spectrum of $\mathrm{C} \times 26$ disorders: Bart- Pumphrey syndrome is caused by a novel missense mutation in GJB2. J Invest Dermat 123: 56-863.

71. Uyguner O, Tukel T, Baykal C, Eris H, Emiroglu M, et al. (2002) The nove R75Q mutation in the GJB2 gene causes autosomal dominant hearing loss and palmoplantar keratoderma in a Turkish family. Clin Genet 62: 306-309.

72. Richard G, White TW, Smith LE, Bailey RA, Compton JG, et al. (1998) Functional defects of Cx26 resulting from a heterozygous missense mutation in a family with dominant deaf-mutism and palmoplantar keratoderma. Hum Genet 103: 393-399.

73. Maestrini E, Korge BP, Ocana-Sierra J, Calzolari E, Cambiaghi S, et al. (1999) A missense mutation in connexin $26, \mathrm{D} 66 \mathrm{H}$, causes mutilating keratoderma with sensorineural deafness (Vohwinkel's syndrome) in three unrelated families. Hum Mol Genet 8: 1237-1243.

74. Snoeckx RL, Hassan DM, Kamal NM, Bogaert VDK, Camp VG (2005) Mutation analysis of the GJB2 (connexin 26) gene in Egypt. Hum Mut 26: 60-61.

75. Morle L, Bozon M, Alloisio N, Latour P, Vandenberghe A, et al. (2000) A novel $\mathrm{C} 202 \mathrm{~F}$ mutation in the connexin 26 gene (GJB2) associated with autosomal dominant isolated hearing loss. J Med Genet 37: 368-370.

76. Loffler J, Nekahm D, Hirst-Stadlmann A, Gunther B, Menzel HJ, et al. (2001) Sensorineural hearing loss and the incidence of Cx26 mutations in Austria. Europ J Hum Genet 9: 226-230.

77. Denoyelle L, Bozon M, Alloisio N, Latour P, Vandenberghe A, et al. (2000) A novel C202F mutation in the connexin 26 gene (GJB2) associated with autosomal dominant isolated hearing loss. J Med Genet 37: 368-370.

78. Hamelmann C, Amedofu GK, Albrecht K, Muntau B, Gelhaus A, et al. (2001) Pattern of connexin GJB2) mutations causing sensorineural hearing impairment in Ghana. Hum Mut 18: 84-85.

79. Primignani $P$, Castorina $P$, Sironi F, Curcio C, Ambrosetti U, et al. (2003) A novel dominant missense mutation D1-79N-in the GJB2 gene (Connexin 26) associated with non-syndromic hearing loss. Clin Genet 63: 516-521.

80. Bruzzone R, White TW, Goodenough DA (1996) The cellular Internet: On-line with connexins. Bioessays 18: 709-718.

81. Gualandi F, Ravani A, Berto A, Sensi A, Trabanelli C, et al. (2002) Exploring the Clinical and Epidemiological Complexity of GJB2-Linked Deafness. Am J Med Genet 112: 38-45.

82. Konigsmark BW, Gorlin RJ (1976) Genetic and metabolic deafness. (1st edn), Saunders, Philaldelphia, USA.

83. Gorlin RJ, Toriello HV, Cohen MM (1995) Hereditary hearing loss and its syndromes. Oxford University Press. New York, USA.
84. Yan D, Liu XZ (2010) Genetics and pathological mechanisms of Usher syndrome. J Hum Genet 55: 327-335.

85. Audo I, Bujakowska K, Saïd SM, Tronche S, Lancelot ME, et al. (2001) A nove DFNB31 mutation associated with Usher type 2 syndrome showing variable degrees of auditory loss in a consanguineous Portuguese family. Mol Ver 17: 1598-1606.

86. Arden GB, Fox B (1979) Increased incidence of abnormal nasal cilia in patients with retinitis pigmentosa. Nature 279: 534-536.

87. Marietta J, Walters KS, Burgess R, Ni L, Fukushima K, et al. (1997) Usher's syndrome type IC: clinical studies and fine-mapping the disease locus. Ann Otol, Rhinol Laryng 106: 123-128.

88. Zrada SE, Braat K, Doty RL, Laties AM (1996) Olfactory loss in Usher syndrome: Another sensory deficit? Am J Med Genet 64: 602-603.

89. Wester DC, Atkin CL, Gregory MC (1995) Alport syndrome: A clinical update. J Am Acad Audio 6: 73-79.

90. Ahmad NN, Ala-Kokko L, Knowlton RG, Jimenez SA, Weaver EJ, et al. (1991) Stop codon in the procollagen II gene (COL2A1) in a family with the Stickler syndrome (arthro-ophthalmopathy). Proc Nat Acad Sci USA 88: 6624-6627.

91. Fraser Gr (1965) Association of congenital deafness with goitre (Pendred's syndrome) a study of 207 families. Ann Hum Genet 28: 201-249.

92. Chen A, Francis M, Ni L, Cremers CW, Kimberling WJ, et al. (1995) Phenotypic manifestations of branchio-oto-renal syndrome. Am J Med Genet 58: 365-370.

93. Finsterer J, Fellinger J (2000) Nuclear and mitochondrial genes mutated in nonsyndromic impaired hearing. Int J Ped Otorhinolaryng 69: 621-647.

94. Guan MX (2011) Mitochondrial 12S rRNA mutations associated with aminoglycoside ototoxicity. Mitochondrion. 11: 237-245.

95. Shabbir MI (2008) Prevalence of different deafness loci in Pakistani inbred families. National Center of Excellence in Molecular Biology, University of the Pubjab, Lahore, Pakistan.

96. Bleeker-Wagemakers LM, Friedrich U, Gal A, Wienker TF, Warburg M, et al (1985) Close linkage between Norrie disease, a cloned DNA sequence from the proximal short arm, and the centromere of the X chromosome. Hum Genet 71: 211-214.

97. Berger W, Meindl A, Van de Pol TJ, Cremers FP, Ropers HH, et al. (1992) Isolation of a candidate gene for Norrie disease by positional cloning. Nat Genet 2: 84.

98. Gal A, Wieringa B, Smeets DF, Bleeker-Wagemakers L, Ropers HH (1986) Submicroscopic interstitial deletion of the $X$ chromosome explains a complex genetic syndrome dominated by Norrie disease. Cytogenet Cell Genet 42 : 219-224.

99. Sims KB, Ozelius L, Corey T, Rinehart WB, Liberfarb R, et al. (1989) et al Norrie disease gene is distinct from the monoamine oxidase genes. Am J Hum Genet 45: 424-434.

100. Berger W, Meindl A, Van de Pol TJ, Cremers FP, Ropers HH, et al. (1992) Isolation of a candidate gene for Norrie disease by positional cloning. Nat Genet 2: 84.

101. Meindl A, Berger W, Meitinger T, Van de Pol D, Achatz $\mathrm{H}$, et al. (1992) Norrie disease is caused by mutations in an extracellular protein resembling C-terminal globular domain of mucins. Nat Genet 2: 139-143.

102. Chen Z Y, Battinelli EM, Fielder A, Bundey S, Sims K, et al. (1993) A mutation in the Norrie disease gene (NDP) associated with X-linked familial exudative vitreoretinopathy. Nat Genet 5: 180-183.

103. Schuback DE, Chen ZY, Craig IW, Breakefield XO, Sims KB (1995) Mutations in the Norrie disease gene. Human Mutation 5: 285-292.

104. Royer G, Hanein S, Raclin V, Gigarel N, Rozet JM, et al. (2003) NDP gene mutations in 14 French families with Norrie disease. Hum Mut 22: 99.

105. Staropoli JF, Xin W, Sims KB (2010) Co-segregation of Norrie disease and idiopathic pulmonary hypertension in a family with a microdeletion of the NDP region at Xp11.3-p11.4. J Med Genet 47: 786-790. 